Article

\title{
Effect of Organic, Inorganic Fertilizers and Plant Spacing on the Growth and Yield of Cabbage
}

\author{
Md Ashraful Islam ${ }^{1}$, Golam Ferdous ${ }^{1}$, Ayasha Akter ${ }^{1}$, Md Mokter Hossain ${ }^{1}$ and \\ Dilip Nandwani ${ }^{2, *}$ \\ 1 Department of Horticulture, Bangladesh Agriculture University (BAU), Mymensingh 2202, Bangladesh; \\ ashrafulmi@bau.edu.bd (M.A.I.); anik286.bau@gmail.com (G.F); aakter.akhy@gmail.com (A.A.); \\ hossainmdmokter@gmail.com (M.M.H.) \\ 2 Department of Agriculture and Environmental Sciences, College of Agriculture, Human and Natural \\ Sciences, Tennessee State University, Nashville, TN 37209, USA \\ * Correspondence: dnandwan@tnstate.edu; Tel: +1-615-963-1897
}

Academic Editor: Guodong Liu

Received: 28 December 2016; Accepted: 23 March 2017; Published: 29 March 2017

\begin{abstract}
The impact of chemical farming and the negative consequences on the environment and human health in Bangladesh are on the rise. Organic farming is gaining attention and increasing globally because it is eco-friendly, safe and has benefits for human health. A field study was conducted at the horticulture farm of Bangladesh Agricultural University (BAU), Mymensingh, to evaluate the growth and yield performance of cabbage cv. Atlas-70 using organic and inorganic fertilizers in various plant spacing arrangements. Two factor experiments were conducted on plant spacings of $60 \mathrm{~cm} \times 40 \mathrm{~cm}\left(\mathrm{~S}_{1}\right), 60 \mathrm{~cm} \times 50 \mathrm{~cm}\left(\mathrm{~S}_{2}\right)$ and $60 \mathrm{~cm} \times 60 \mathrm{~cm}\left(\mathrm{~S}_{3}\right)$ and fertilizers vermicompost $\left(T_{1}\right)$, biogen $\left(T_{2}\right)$, integrated plant nutrient system (IPNS) Organic $(2 / 3)+$ inorganic $(1 / 3)\left(T_{3}\right)$ and inorganic $\left(\mathrm{T}_{4}\right)$. IPNS $\left(\mathrm{T}_{3}\right)$ application increased the marketable yield $\left(54.77 \mathrm{t} \cdot \mathrm{ha}^{-1}\right)$ of cabbage. The highest marketable yield $\left(48.75 \mathrm{t} \cdot \mathrm{ha}^{-1}\right)$ was obtained with a plant spacing of $60 \mathrm{~cm} \times 40 \mathrm{~cm}$ $\left(S_{1}\right)$. No significant variation was found in plant spacings $S_{1}$ and $S_{2}$. The treatment combination of $\mathrm{S}_{2} \mathrm{~T}_{3}$ recorded the highest plant height $(37.81 \mathrm{~cm})$, plant spread $(47.75 \mathrm{~cm})$, cabbage head $(21.80 \mathrm{~cm})$, stem length $(12.31 \mathrm{~cm})$, thickness of the cabbage head $(12.53 \mathrm{~cm})$ and marketable yield $\left(65.0 \mathrm{t} \cdot \mathrm{ha}^{-1}\right)$. The results suggest that IPNS $\left(\mathrm{T}_{3}\right)$ combining organic and inorganic fertilizer applications with a $60 \mathrm{~cm} \times 50 \mathrm{~cm}$ spacing $\left(\mathrm{S}_{2} \mathrm{~T}_{3}\right)$ increases the yield performance of cabbage.
\end{abstract}

Keywords: biogen; cabbage; growth; plant density; vermicompost; yield

\section{Introduction}

The sustainability of conventional agriculture in Bangladesh is under threat from the continuous degradation of land and water resources, as well as declining yield due to indiscriminate use of agro-chemicals. Use of synthetic fertilizers and pesticides in agriculture production increased tremendously after the green revolution [1,2]. Environmental impacts of excessive applications of chemical fertilizers in Bangladesh have been reported [3].Excessive use of chemical fertilizers causes unforeseen environmental impacts and sensitivity to pests and diseases through the oversupply of nitrogen [4]. Organic farming practices are a potential way to decrease the negative environmental impact of excessive amounts of chemical fertilizers [5,6]. Organic fertilizers are environmentally friendly and improve soil health, water-holding capacity, high cation exchange capacity and low bulk density and they a foster diverse population of beneficial soil microorganisms [7-9]. Alternatively, there are mixed fertilizers or integrated plant nutrient systems (IPNS) where organic fertilizer is combined with inorganic fertilizer for soil improvement and higher yield. This reduces the dependency and need for a higher amount of inorganic fertilizer in crop production. Organic fertilizers contain 
macro- and micro-nutrients, vitamins, growth-promoting factors indole 3-acetic acid (IAA), gibberellic acid (GA), and beneficial microorganisms $[10,11]$, and they increase production in ways similar to inorganic fertilizers [12-17]. Cabbage (Brassica oleracea var. capitate L.), is a nutritious and high-value leafy vegetable in Bangladesh [18] and it is widely grown in both tropical and temperate regions. The major cabbage-growing countries of the world are South Korea, Germany, Japan, India, South Africa and China. The average yield of cabbage in Bangladesh is far lower $\left(13.25 \mathrm{t} \cdot \mathrm{ha}^{-1}\right)$ than other countries $\left(32.31 \mathrm{t} \cdot \mathrm{ha}^{-1}\right)[19,20]$. Plant spacing and fertilizer applications have significant influence on the growth and yield in crop production. Optimum plant spacing ensures the proper use of land, as well as growth and nutrition in plants. The judicial application of organic or inorganic fertilizers is an important consideration to improve the yield and quality of the product. Earlier reports suggest that a combined application of manures and fertilizers (integrated plant nutrient system, IPNS) increases the yield and improves the quality of vegetables [21]. The objective of the work is to evaluate the growth and yield performance of cabbage in various plant spacing arrangements using different organic and inorganic fertilizers.

\section{Materials and Methods}

The experiment was conducted at the Horticulture Farm of Bangladesh Agricultural University (BAU), Mymensingh during November 2014 to February 2015 on cabbage cv. Atlas-70. Seeds (hybrid $\mathrm{F}_{1}$ ) obtained locally (Sakata Seed Corporation, Japan). Soil samples of experimental plot collected from various places depth of $15 \mathrm{~cm}$ and sent to Agrivarsity Humboldt Soil Testing Laboratory for analysis. Two factors experiment was laid out in a Randomized Complete Block Design (RCBD) with three replications. The double factor experiment consisted of three plant spacings, $60 \mathrm{~cm} \times 40 \mathrm{~cm}\left(\mathrm{~S}_{1}\right), 60 \mathrm{~cm} \times 50 \mathrm{~cm}\left(\mathrm{~S}_{2}\right)$ and $60 \mathrm{~cm} \times 60 \mathrm{~cm}\left(\mathrm{~S}_{3}\right)$. Four fertilizer treatments applied, vermicompost@17 th.ha ${ }^{-1}\left(T_{1}\right)$, Biogen@15 th.ha ${ }^{-1}\left(T_{2}\right)$, integrated plant nutrient system (IPNS) @ 2/3 organic fertilizer+1/3 inorganic fertilizer $\left(\mathrm{T}_{3}\right)$ and Inorganic (Urea@326 kg.ha ${ }^{-1}$, TSP@104 kg $\cdot \mathrm{ha}^{-1}$, MoP@120 kg.ha ${ }^{-1}$, Boric acid@5.88 kg.ha ${ }^{-1}$ and Zinc sulphate@5.55 kg.ha $\left.{ }^{-1}\right)\left(\mathrm{T}_{4}\right)$. In the IPNS system, two-thirds part organic fertilizer consists of equal amount of vermicompost and Biogen fertilizers. Fifteen, 12 and 9 plants were planted in each plot $(1.8 \mathrm{~m} \times 2.0 \mathrm{~m})$, in three spacing $\mathrm{S}_{1}, \mathrm{~S}_{2}$, and $\mathrm{S}_{3}$, respectively. Inorganic fertilizer was used as control. Biogen fertilizer (MATI Organics Ltd., Dhaka, Bangladesh) nutritional composition was N (0.5\%-4.0\%), P (0.3\%-0.5\%), K (0.3\%-0.5\%), S $(0.1 \%-0.5 \%)$, $\mathrm{Zn}(0.1 \%)$ and $\mathrm{Cu}(0.05 \%)$. Vermicompost was obtained from Horticulture farm of BAU. In Bangladesh, vermicompost nutrient composition is varies $(\mathrm{N}: 0.5 \%-4 \%, \mathrm{P}: 0.5 \%-3 \%, \mathrm{~K}: 0.5 \%-3 \%$, and $\mathrm{S}: 0.1 \%-0.5 \%$, personal contact with BARC, Bangladesh). Seedlings were raised in seedbeds $(3 \mathrm{~m} \times 1 \mathrm{~m})$ and field was prepared with a power tiller. Organic fertilizers (vermicompost and biogen), triple superphosphate (TSP), $\mathrm{ZnSO}_{4}$, and boric acid were applied before planting. Inorganic fertilizers (urea and potash) were applied in two parts at 15 and 35 days after transplanting as band application [22]. Healthy transplants (three weeks old) were selected from the seedbed and transplanted in the experimental plots. Planting was done in the afternoon to avoid transplanting shock. Seedlings were watered after transplanting. Banana leaves were used around seedlings as mulch. Weeding and irrigation were done manually. Five plants were selected randomly for data collection in each plot and labeled. Data collected on plant height, plant diameter, stem length, head thickness, and head diameter. Marketable weight (compact head) per plant was measured and total marketable yield recorded. Data were statistically analyzed with MSTAT-C software. The means for all the characters were performed by $F$ test. The mean differences among the treatments were evaluated with LSD test at $1 \%$ and $5 \%$ level of significance [23].

\section{Results and Discussion}

The soil analysis before the planting and after the harvesting of cabbage indicated the soil organic matter content was $2.55 \%$ and $2.60 \%$, respectively. During planting, the soil $\mathrm{pH}$ was 6.43 and the electrical conductivity $(\mathrm{EC})$ was $72.54(\mu \mathrm{c} / \mathrm{cm})$. The soil $\mathrm{pH}$ and EC increased after harvesting the 
crop [24].The average yield of cabbage was significantly influenced by the organic and inorganic fertilizer treatments and plant spacings. The plant height was recorded at 15, 30, 45 and 60 days after transplanting (DAT). The plant height was significantly different $(p \leq 0.01)$ between the fertilizer and spacing treatments. The spread of the cabbage plant data was recorded at 15, 30, 45 and 60 DAT. The maximum spread of plants $(47.57 \mathrm{~cm})$ was at 60 DAT observed in IPNS $\left(\mathrm{T}_{3}\right)$, followed by the vermicompost $\left(\mathrm{T}_{1}\right)(44.34 \mathrm{~cm})$ and inorganic fertilizer $\left(\mathrm{T}_{4}\right)(41.97 \mathrm{~cm})$ applications. In earlier reports, the $60 \mathrm{~cm} \times 50 \mathrm{~cm}$ spacing was suitable for plant growth [25]. In the combined effect at 60 DAT, the treatment $\mathrm{S}_{2} \mathrm{~T}_{3}(60 \mathrm{~cm} \times 50 \mathrm{~cm}$ spacing $) \times(2 / 3$ organic $+1 / 3$ inorganic $)$ showed the highest mean height of cabbage $(37.81 \mathrm{~cm})$ followed by the treatments $\mathrm{S}_{3} \mathrm{~T}_{3}(35.96 \mathrm{~cm})$ and $\mathrm{S}_{2} \mathrm{~T}_{2}(35.73 \mathrm{~cm})$. The lowest mean height of cabbage $(33.03 \mathrm{~cm})$ was produced from the treatment $\mathrm{S}_{1} \mathrm{~T}_{4}$ (Table 1). Results showed that the wider spacing was superior in yield attributes. Similar findings in the plant height of cabbage were obtained by various researchers $[25,26]$ and IPNS or the application of mixed fertilizers influenced the plant height $[27,28]$. The wider spacing did not produce highest yield as number of plants reduced by the unit area. The results indicated that application of organic fertilizers and inorganic fertilizers combined showed improved growth and the maximum plant spread. These findings are in agreement with the reports where vermicompost or poultry manure along with inorganic fertilizer application yielded high plant spread [27-29].

Table 1. Effect of organic and inorganic fertilizers and spacing on plant height and the spread of the cabbage at different days after transplanting (DAT).

\begin{tabular}{ccccc|cccc}
\hline $\begin{array}{c}\text { Treatment } \\
\text { Combinations }\end{array}$ & \multicolumn{3}{c}{ Plant Height $(\mathbf{c m})$ at DAT } & \multicolumn{3}{c}{ Spread of the Plant $(\mathbf{c m})$ at DAT } \\
\cline { 2 - 9 } & $\mathbf{1 5}$ & $\mathbf{3 0}$ & $\mathbf{4 5}$ & $\mathbf{6 0}$ & $\mathbf{1 5}$ & $\mathbf{3 0}$ & $\mathbf{4 5}$ & $\mathbf{6 0}$ \\
\hline $\mathrm{S}_{1} \mathrm{~T}_{1}$ & 9.76 & 20.45 & 30.62 & 33.31 & 13.39 & 26.54 & 34.77 & 43.90 \\
$\mathrm{~S}_{1} \mathrm{~T}_{2}$ & 9.83 & 22.11 & 31.25 & 33.37 & 13.16 & 26.53 & 34.67 & 43.20 \\
$\mathrm{~S}_{1} \mathrm{~T}_{3}$ & 10.60 & 23.99 & 33.30 & 35.85 & 14.63 & 29.09 & 36.50 & 45.57 \\
$\mathrm{~S}_{1} \mathrm{~T}_{4}$ & 9.15 & 21.85 & 30.52 & 33.03 & 12.30 & 24.63 & 33.04 & 41.19 \\
$\mathrm{~S}_{2} \mathrm{~T}_{1}$ & 9.90 & 21.66 & 30.83 & 34.38 & 14.00 & 28.83 & 36.07 & 44.67 \\
$\mathrm{~S}_{2} \mathrm{~T}_{2}$ & 10.65 & 22.85 & 33.47 & 35.73 & 14.40 & 28.38 & 36.35 & 44.87 \\
$\mathrm{~S}_{2} \mathrm{~T}_{3}$ & 12.00 & 25.49 & 35.73 & 37.81 & 15.57 & 29.90 & 38.50 & 47.75 \\
$\mathrm{~S}_{2} \mathrm{~T}_{4}$ & 10.93 & 22.84 & 32.69 & 34.67 & 13.54 & 27.28 & 34.08 & 42.40 \\
$\mathrm{~S}_{3} \mathrm{~T}_{1}$ & 9.83 & 20.70 & 30.66 & 33.92 & 13.60 & 26.77 & 34.82 & 44.45 \\
$\mathrm{~S}_{3} \mathrm{~T}_{2}$ & 10.03 & 22.35 & 32.11 & 34.99 & 14.24 & 27.85 & 35.50 & 43.79 \\
$\mathrm{~S}_{3} \mathrm{~T}_{3}$ & 11.28 & 25.47 & 34.35 & 35.96 & 14.91 & 29.40 & 38.15 & 46.40 \\
$\mathrm{~S}_{3} \mathrm{~T}_{4}$ & 9.67 & 22.71 & 32.06 & 34.25 & 12.67 & 25.93 & 33.97 & 42.33 \\
\hline $\mathrm{LSD}_{0.05}$ & 0.541 & 0.186 & 0.533 & 0.579 & 1.380 & 0.505 & 0.347 & 0.780 \\
$\mathrm{LSD}_{0.01}$ & 0.735 & 0.252 & 0.724 & 0.787 & 1.876 & 0.687 & 0.472 & 1.060 \\
\hline Level of significance & $* * *$ & $* *$ & $* *$ & $* *$ & NS & $* *$ & $* *$ & $* *$ \\
\hline $\mathrm{S}_{1}=60 \mathrm{~cm} \times 40 \mathrm{~cm} ; \mathrm{T}_{1}=$ Vermicompost; $\mathrm{S}_{2}=60 \mathrm{~cm} \times 50 \mathrm{~cm} ; \mathrm{T}_{2}=$ Biogen; $\mathrm{S}_{3}=60 \mathrm{~cm} \times 60 \mathrm{~cm} ; \mathrm{T}_{3}=$ IPNS $(2 / 3$ organic \\
$+1 / 3$ inorganic) and $\mathrm{T}_{4}=$ Inorganic; ** Significant at $1 \%$ level of probability. NS: Non-Significant.
\end{tabular}

The highest yield was obtained from the integrated plant nutrient system (IPNS, $\mathrm{T}_{3}$ ) compared to the other treatments of organic fertilizer, biogen and inorganic fertilizers (data not shown). Higher yields obtained were with mixed fertilizers over other fertilizer applications. The combined treatment $\mathrm{S}_{2} \mathrm{~T}_{3}(60 \mathrm{~cm} \times 50 \mathrm{~cm}$ spacing $) \times(2 / 3$ organic $+1 / 3$ inorganic $)$ showed the highest length of stems $(12.31 \mathrm{~cm})$ followed by $\mathrm{S}_{2} \mathrm{~T}_{2}(12.01 \mathrm{~cm})$, while the lowest length of stems was recorded in $\mathrm{S}_{1} \mathrm{~T}_{4}$ $(10.60 \mathrm{~cm})$ (Table 2). Sharma [30] found that the integrated application of organic and inorganic fertilizers significantly increased the vegetative growth.

The plant spacing of $60 \mathrm{~cm} \times 50 \mathrm{~cm}\left(\mathrm{~S}_{2}\right)$ produced the highest number of roots per plant. The highest number of roots was recorded from the IPNS treatment followed by $\mathrm{T}_{1}$, while the lowest number of roots was obtained from the $\mathrm{T}_{4}$ treatment. The highest number of roots (16.20/plant) was produced from the $\mathrm{S}_{2} \mathrm{~T}_{3}$ treatment $(60 \mathrm{~cm} \times 50 \mathrm{~cm}) \times(2 / 3$ organic $+1 / 3$ inorganic $)$, while the lowest number of roots was found in the $\mathrm{S}_{1} \mathrm{~T}_{4}$ treatment (12.53/plant) (Table 2). Rai et al. [27] reported similar findings that when vermicompost was applied in the soil with NPK (nitrogen-phosphorous-potassium), 
some metallic trace elements stimulated the growth of roots [28]. A higher number of roots indicate improved growth in the combined treatment and higher yield.

Table 2. Effects of organic and inorganic fertilizers with different spacing on yield and yield-contributing characteristics of cabbage.

\begin{tabular}{|c|c|c|c|c|c|c|c|}
\hline $\begin{array}{c}\text { Treatment } \\
\text { Combinations }\end{array}$ & $\begin{array}{c}\text { Head } \\
\text { Diameter } \\
(\mathrm{cm})\end{array}$ & $\begin{array}{c}\text { Root } \\
\text { Length } \\
(\mathrm{cm})\end{array}$ & $\begin{array}{c}\text { Stem } \\
\text { Length } \\
(\mathrm{cm})\end{array}$ & $\begin{array}{l}\text { Number } \\
\text { of Roots } \\
\text { Plant }^{-1}\end{array}$ & $\begin{array}{c}\text { Head } \\
\text { Thickness } \\
\text { (cm) }\end{array}$ & $\begin{array}{l}\text { Marketable } \\
\text { Weight } \\
\left(\mathrm{kg} \cdot \text { plant }^{-1}\right)\end{array}$ & $\begin{array}{c}\text { Marketable } \\
\text { Yield } \\
\left(\mathrm{t} \cdot \mathrm{ha}^{-1}\right)\end{array}$ \\
\hline $\mathrm{S}_{1} \mathrm{~T}_{1}$ & 18.07 & 17.69 & 10.91 & 13.80 & 10.25 & 1.03 & 42.91 \\
\hline $\mathrm{S}_{1} \mathrm{~T}_{2}$ & 19.33 & 17.65 & 11.07 & 13.93 & 11.23 & 1.10 & 45.83 \\
\hline$S_{1} T_{3}$ & 20.07 & 18.65 & 11.27 & 14.47 & 11.42 & 1.46 & 60.83 \\
\hline $\mathrm{S}_{1} \mathrm{~T}_{4}$ & 18.80 & 18.39 & 10.60 & 12.53 & 10.55 & 1.09 & 45.42 \\
\hline $\mathrm{S}_{2} \mathrm{~T}_{1}$ & 19.68 & 19.90 & 11.51 & 15.67 & 11.58 & 1.13 & 37.67 \\
\hline $\mathrm{S}_{2} \mathrm{~T}_{2}$ & 19.98 & 19.50 & 12.01 & 15.53 & 11.46 & 1.40 & 46.33 \\
\hline $\mathrm{S}_{2} \mathrm{~T}_{3}$ & 21.80 & 19.66 & 12.31 & 16.20 & 12.53 & 1.95 & 65.00 \\
\hline $\mathrm{S}_{2} \mathrm{~T}_{4}$ & 19.97 & 20.37 & 11.42 & 13.67 & 11.26 & 1.31 & 43.67 \\
\hline $\mathrm{S}_{3} \mathrm{~T}_{1}$ & 18.80 & 17.75 & 11.19 & 14.73 & 10.75 & 1.11 & 30.81 \\
\hline $\mathrm{S}_{3} \mathrm{~T}_{2}$ & 19.83 & 18.90 & 11.39 & 14.47 & 11.25 & 1.21 & 30.25 \\
\hline $\mathrm{S}_{3} \mathrm{~T}_{3}$ & 20.45 & 19.06 & 11.39 & 14.73 & 11.52 & 1.54 & 38.50 \\
\hline $\mathrm{S}_{3} \mathrm{~T}_{4}$ & 19.01 & 19.40 & 11.16 & 13.33 & 10.80 & 1.15 & 37.75 \\
\hline $\mathrm{LSD}_{0.05}$ & 0.522 & 0.502 & 0.257 & 0.227 & 0.200 & 0.107 & 1.90 \\
\hline $\mathrm{LSD}_{0.01}$ & 0.709 & 0.683 & 0.349 & 0.309 & 0.272 & 0.146 & 2.58 \\
\hline Level of significance & $* *$ & $* *$ & $* *$ & $* *$ & $* *$ & $* *$ & $* *$ \\
\hline
\end{tabular}

The longest roots $(20.37 \mathrm{~cm})$ and shortest roots $(17.65 \mathrm{~cm})$ were recorded in combined treatments $\mathrm{S}_{2} \mathrm{~T}_{4}(60 \mathrm{~cm} \times 50 \mathrm{~cm}$ spacing $) \times$ (inorganic) and $\mathrm{S}_{1} \mathrm{~T}_{2}$, respectively (Table 2).Earlier reports suggest that plants grown in wider spacing produced the highest root length due to the low density of plants per unit area $[26,31]$.

The combined treatment of fertilizers $\left(\mathrm{T}_{3}\right)$ and spacing treatments $\left(\mathrm{S}_{2}\right)\left(\mathrm{S}_{2} \mathrm{~T}_{3}\right)$ provided the highest thickness of the cabbage $(12.53 \mathrm{~cm})$ in the treatment $S_{2} T_{3}(60 \mathrm{~cm} \times 50 \mathrm{~cm}) \times(2 / 3$ organic $+1 / 3$ inorganic) and the lowest $\left(10.25 \mathrm{~cm}\right.$ ) in the treatment $S_{1} T_{1}$ (Table 2). Haque [29] reported that the effect of the mixed fertilizer application (organic and inorganic) resulted in the highest thickness of the cabbage head.

This compactness also has the rational trend of the combination where a higher yield was obtained (Table 2). $S_{2}$ showed improved growth and yield compared to $S_{1}$. This illustrated that there was a higher plant density and population per plot in $S_{2}$ compared to $S_{1}$. The treatment $S_{2}$ recorded the highest and $S_{1}$ obtained the lowest diameter of the cabbage head. The highest diameter of the cabbage head was recorded from the treatment $S_{2} T_{3}(60 \mathrm{~cm} \times 50 \mathrm{~cm}) \times(2 / 3$ organic $+1 / 3$ inorganic) followed by the treatments $\mathrm{S}_{3} \mathrm{~T}_{3}(20.45 \mathrm{~cm})$ and $\mathrm{S}_{1} \mathrm{~T}_{3}(20.07 \mathrm{~cm})$, and the lowest was obtained from the treatment $\mathrm{S}_{1} \mathrm{~T}_{1}$ (Table 2). These results are in agreement with previous reports where poultry manure and NPK had a higher head diameter compared to the control [29,32]. Kedino et al. [33] reported a higher head diameter in combined organic and inorganic fertilizer (FYM + NPK) applications.

The combined treatment of spacing and fertilizers $\mathrm{S}_{2} \mathrm{~T}_{3}(60 \mathrm{~cm} \times 50 \mathrm{~cm}) \times(2 / 3$ organic + $1 / 3$ inorganic) produced the highest marketable weight $\left(1.95 \mathrm{~kg} \cdot\right.$ plant $\left.^{-1}\right)$ (Table 2). The highest marketable yield was obtained in the plant spacing $S_{1}$ compared to $S_{3}$ and $S_{2}$ (data not shown). It was hypothesized that there was a lower yield in higher plant spacing due to lower plant numbers. The plant spacing $T_{2}$ showed the best performance, except in the thickness of the cabbage and the diameter of the cabbage. No significant yield was found among the plant spacings $S_{2}$ and $S_{1}$. The marketable yield of the cabbage was highest in IPNS compared to other fertilizers treatments. In combination, IPNS fitted very well with the plant spacing $T_{2} . S_{1}, S_{2}$ and $S_{3}$ showed improved yield with IPNS compared to vermicompost, biogen and inorganic fertilizer (Table 2). IPNS showed improved results in our tomato trial compared with different types of organic and inorganic fertilizers, 
conducted in the same year and at the same location of the cabbage experiment (Horticulture farm of BAU) [24]. The $S_{2} T_{3}$ application recorded the highest and $S_{3} T_{2}$ recorded the lowest marketable yield in cabbage, which is in agreement with previous reports of cabbage and tomato [26,32,34-36].

\section{Conclusions}

The study showed that the integrated plant nutrient system (IPNS) is suitable for the improved growth and yield of cabbage with plant spacing $\left(\mathrm{S}_{2}, 60 \mathrm{~cm} \times 50 \mathrm{~cm}\right)$. Organic and inorganic mixed fertilizers in a $60 \mathrm{~cm} \times 50 \mathrm{~cm}$ spacing $\left(\mathrm{S}_{2} \mathrm{~T}_{3}\right)$ have the potential to enhance yield in cabbage and to reduce the quantity and doses of inorganic fertilizer.

Acknowledgments: The corresponding author expresses sincere thanks to USDA-FAS for funding support. Our sincere appreciation to MATI organic for providing biogen fertilizer. Thanks to George Smith for reviewing the manuscript.

Author Contributions: Md Ashraful Islam designed field experiment, conducted data analysis and prepared manuscript. G. Ferdous assisted in the field data collection. A. Akter helped in manuscript writing. M.M. Hossain assisted in manuscript review. D. Nandwani supervised the project overall.

Conflicts of Interest: The authors declare no conflict of interest.

\section{References}

1. Dürdane, Y.; Naif, G.; Yusuf, Y.; Mine, A.; Perihan, C. Effect of different organic fertilizers on yield and fruit quality of indeterminate tomato (Lycopersicon esculentum). Sci. Res. Essays 2011, 6, 3623-3628.

2. Goutam, K.C.; Goutam, B.; Susanta, K.C. The effect of vermicompost and other fertilizers on cultivation of tomato plants. J. Hortic. For. 2011, 3, 42-45.

3. Muhibbullah, M.; Momotaz, S.; Chowdhury, A.T. Use of agrochemical fertilizers and their impact on soil, water and human health in the Khamargao Village of Mymensingh District, Bangladesh. J. Agron. 2005, 4, 109-115.

4. Chen, J.H. The combined use of chemical and organic fertilizers and/or biofertilizer for crop growth and soil fertility. In Proceedings of the International Workshop on Sustained Management of the Soil-Rhizosphere System for Efficient Crop Production and Fertilizer Use, Bangkok, Thailand, 16-20 October 2006.

5. Aksoy, U. Ecological farming. II. In Proceedings of the Ecological Farming Symposium, Antalya, Turkey, 14-16 December 2001.

6. Chowdhury, R. Effects of chemical fertilizers on the surrounding environment and the alternative to the chemical fertilizers. Ies. Envis Newsl. 2004, 7, 4-5.

7. Bulluck, L.R.; Brosius, M.; Evanylo, G.K.; Ristain, J.B. Organic and synthetic fertility amendments influence soil microbial, physical and chemical properties on organic and conventional farms. Appl. Soil Ecol. 2002, 19, 147-160. [CrossRef]

8. Oyewole, C.; Opaluwa, H.; Omale, R. Response of tomato (Lycopersicon esculentum) growth and yield to rates of mineral and poultry manure application in the Guinea Savanna Agro-ecological Zone in Nigeria. J. Biol. Agric. Healthc. 2012, 2, 44-56.

9. Mohammad, M.; Ebrahim, I.D.; Houshang, N.R.; Ahmad, T. Growth and yield of tomato (Lycopersicon esculentum Mill.) as influenced by different organic fertilizers. Int. J. Agron. Plant Prod. 2013, 4, 734-738.

10. Natarajan, K. Panchagavya for plant. In Proceedings of the National Conference, Glory Gomatha, 1-3 December 2007; S.V. Veterinary University: Tirupati, India; pp. 72-75.

11. Sreenivasa, M.N.; Nagaraj, M.N.; Bhat, S.N. Beejamruth: A source for beneficial bacteria. Karnataka J. Agric. Sci. 2010, 17, 72-77.

12. Bulluck, L.R.; Ristaino, J.B. Effect of synthetic and organic soil fertility amendments on southern blight, soil microbial communities, and yield of processing tomatoes. Phytopathology 2002, 92, 181-189. [CrossRef] [PubMed]

13. Arancon, N.Q.; Edwards, C.A.; Bierman, P.; Metzger, J.D.; Lee, S.; Welch, C. Effects of vermicompost on growth and marketable fruits of field-grown tomatoes, peppers and strawberries. Pedobiologia 2004, 47, 731-735. [CrossRef] 
14. Heeb, A.; Lundegardh, B.; Savage, G.P.; Ericsson, T. Impact of organic and inorganic fertilizers on yield, taste, and nutritional quality of tomatoes. J. Plant Nutr. Soil Sci. 2006, 169, 535-541. [CrossRef]

15. Liu, B.; Gumpertz, M.L.; Hu, S.; Ristaino, J.B. Long-term effects of organic and synthetic soil fertility amendments on soil microbial communities and the development of southern blight. Soil Biol. Biochem. 2007, 39, 2302-2316. [CrossRef]

16. Maske, S.N.; Munde, G.R.; Maske, N.M. Effect of manures and fertilizer on brinjal (Solanum melongena L.) cv. Krishna. Bioinfolet 2015, 12, 678-679.

17. Tonfack, L.B.; Bernadac, A.; Youmbi, E.; Mbouapouognigni, V.P.; Ngueguim, M.; Akoa, M. Impact of organic and inorganic fertilizers on tomato vigor, yield and fruit composition under tropical andosol soil conditions. Fruits 2009, 64, 167-177. [CrossRef]

18. Beecher, C. Cancer preventive properties of Brassica oleracea: A review. Am. J. Clin. Nutr. 1994, 59, 1166-1170.

19. Bangladesh Bureau of Statistics (BBS). Statistical Year Book of Bangladesh; Statistical Division, Ministry of Planning: Dhaka, Bangladesh, 2013; p. 39.

20. Food and Agriculture Organization (FAO). Production Year Book; Food and Agriculture Organization of the United Nations: Rome, Italy, 2012.

21. Bahadur, A.; Singh, J.; Singh, K.P. Response of cabbage to organic manure and biofertilizers. Indian J. Horti. 2004, 61, 278-279.

22. Miah, M.U.Md.; Jahiruddin, M.; Islam, M.F.; Razia, S. Fertilizer Recommendation Guide; Bangladesh Agricultural Research Council: Dhaka, Bangladesh, 2012; p. 113.

23. Gomez, K.A.; Gomez, A.A. Statistical Procedure for Agricultural Research, 2nd ed.; John Willy and Sons: New York, NY, USA, 1984; pp. 28-192.

24. Islam, M.A.; Islam, S.; Akter, A.; Rahman, M.H.; Nandwani, D. Effect of organic and inorganic fertilizers on soil properties and the growth, yield and quality of tomato in Mymensingh, Bangladesh. Agriculture 2017, 7, 18. [CrossRef]

25. Balvoll, G. Research with Cultivars, Nitrogen, Manuring and Plant Spacing in a Bed System for Winter Cabbage; Institute for Plant: Aas, Norway, 1994.

26. Moniruzzaman, M. Effect of plant spacing on the performance of hybrid cabbage (Brassica oleracea var. capitata) varieties. Bangladesh J. Agric. Res. 2011, 36, 495-506.

27. Rai, R.; Thapa, U.; Mandal, A.R.; Roy, B. Growth, yield and quality of cabbage (Brassica oleracea var capitata L.) as influenced by vermicompost. Environ. Ecol. 2013, 31, 314-317.

28. Sultana, J.; Siddique, M.A.; Rashid, M.H.A. Effects of cowdung and potassium on growth and yield of Kohlrabi. J. Bangladesh Agric. Univ. 2012, 10, 27-32. [CrossRef]

29. Haque, A. Effect of Different Organic Manures on Growth and Yield of Cabbage. Master's Thesis, Department of Horticulture, Patuakhali Science and Technology University (PSTU), Dumki, Patuakhali, Bangladesh, 2012; pp. 1-73.

30. Sharma, K.C. Influence of integrated nutrient management on yield and economics in broccoli (Brassica oleracea L. var. italica) plant under cold temperate conditions. Veg. Sci. 2000, 27, 62-63.

31. Abbasdokht, K.; Jaenaksom, T.; Ikeda, H. Possibility of substituting soil less fertilizer with soil fertilizer with soil fertilizer for growing leafy vegetables in hydroponics. Acta Hortic. 2003, 642, 345-361.

32. Znidarcic, D.; Kacjan-Marsic, N.; Osvald, J.; Pozrl, T.; Trdan, S. Yield and quality of early cabbage (Brassica leracea L. var. capitata) in response to within-Row plant spacing. Acta Agric. Slov. 2007, 89, 15-23.

33. Kedino, Z.; Kanaujia, S.P.; Singh, V.B.; Singh, P.K. Effect of organic manures and biofertilizers on growth, yield and quality of cabbage under foot hill condition of Nagaland. Environ. Ecol. 2009, 27, 1127-1129.

34. Sarkar, M.D. Growth, yield and profitability of cabbage (Brassica oleracea L.) as influenced by applied nitrogen and plant spacing. Agriculturists 2015, 13, 35-45.

35. Pornsuriya, P.; Teeraskulchon, S. Studies on broccoli production in Chonburi Province, Thailand. Kasetsart J. Nat. Sci. 1997, 32, 81-85.

36. Ara, N.; Bashar, M.K.; Begum, S.; Kakon, S.S. Effect of spacing and stem pruning on the growth and yield of tomato. Int. J. Sustain. Crop Prod. 2007, 2, 35-39.

(C) 2017 by the authors. Licensee MDPI, Basel, Switzerland. This article is an open access article distributed under the terms and conditions of the Creative Commons Attribution (CC BY) license (http:/ / creativecommons.org/licenses/by/4.0/). 